\title{
PENGARUH PELAYANAN DAN TEKNOLOGI TERHADAP LOYALITAS NASABAH PADA BANK NAGARI CABANG UTAMA PADANG
}

\author{
Karneli, Febsri Susanti \\ Sekolah Tinggi Ilmu Ekonomi KBP \\ febsrisusanti@akbpstie.ac.id \\ karneli1606@gmail.com
}

\begin{abstract}
Current problems faced by Nagari Bank include delays in determining product development, lack of media promotion and intense competition. In addition, the quality of services provided by Bank Nagari in serving its customers is still not satisfactory. The quality of service is not yet optimal and classified as sluggish compared to other banking companies in the city of Padang. Likewise with the application of technology to the Nagari Bank, it still lags behind other banks. The population used in this study were all Bank Nagari customers in the city of Padang, amounting to 39781 people in 2016. Whereas in the number of samples the Slovin formula was used as many as 100 people. In the independent variable is service and technology, and for the dependent variable is customer loyalty. From the results of testing the second independent variable hypothesis as measured by technology found a significant value of 0.000. In testing the hypothesis set the maximum error is consistent using alpha 0.05 means sig 0.000 <alpha 0.05 Therefore the decision is Ha accepted and Ho is rejected. So it can be concluded that technology has a significant effect on customer loyalty of Bank Nagari Main Branch Padang.
\end{abstract}

Keywords: Service, Technology and Customer Loyalty

\section{PENDAHULUAN}

Dewasa ini bisnis semakin berkembang dan mengalami persaingan yang sangat pesat. Perusahaan mau tidak mau harus mengantisipasi keadaan ini dengan serangkaian strategi yang tepat. Setiap perusahaan, baik perusahaan dagang maupun perusahaan jasa berusaha mempertahankan pelanggannya dengan memberikan pelayanan yang memuaskan. Hal ini disebabkan kesadaran perusahaan bahwa pelanggan adalah nyawa atau kehidupan perusahaan.

Semakin disadari bahwa loyalitas pelanggan merupakan aspek strategis dalam rangka bertahan dan memenangi persaingan yang serba sulit dan global seperti saat ini. Di dalam berhubungan dengan nasabah, perusahaan yang ingin memuaskan nasabahnya tadi harus meningkatkan dan memperbaiki kualitas pelayanan. Konsep kualitas lebih dari sekedar memenuhi spesifikasi barang. Kualitas mengimplikasikan memenuhi atau melebihi harapan tentang ketetapan 
waktu, akurasi pekerjaan, kecepatan tanggapan dan unjuk kerja atau yang seharusnya diterima pelanggan (Yazid, 2008).

Salah satu lembaga perbankan yang beroperasi untuk menghimpun dana dari masyarakat adalah Bank Nagari Cabang Utama Padang. Bank ini merupakan bank yang berperan sebagai kas pemerintahan daerah Sumatera Barat. Bank nagari berupaya melakukan pengembangan produk jasa tabungan dengan tujuan untuk memenuhi keinginan atau harapan nasabah, menghadapi persaingan antara bank umum lain, memperoleh laba yang lebih baik, mempertahankan pasar, memberikan kemudahan pelayanan terhadap nasabah dan mempertahankan eksistensi Bank Nagari.

Permasalahan yang dihadapi Bank Nagari saat ini antara lain keterlambatan dalam menentukan pengembangan produk, kurangnya media promosi dan persaingan yang ketat. Di samping itu, kualitas pelayanan yang diberikan oleh Bank Nagari dalam melayani nasabahnya masih belum memuaskan. Kualitas pelayanan tersebut terasa belum optimal dan tergolong lamban jika dibandingkan dari perusahaan perbankan lainnya yang ada di kota Padang. Begitupun dengan penerapan teknologi pada Bank Nagari masih tertinggal dari bank-bank lainnya.

\section{METODE PENELITIAN}

1. Jenis Penelitian

Jenis Penelitian yang digunakan adalah penelitian kuantitatif yang menjelaskan hubungan sebab akibat dari variabel - variabel independen terhadap variabel dependennya.

2. Populasi dan Sampel

Pengertian populasi menurut para ahli:sebagai wilayah generalisasi yang terdiri atas objek atau subjek yang mempunyai kualitas dan karakteristik tertentu yang ditetapkan oleh peneliti untuk dipelajari kemudian ditarik kesimpulannya (Sugiyono, 2015)

Adapun yang menjadi populasi dalam penelitian ini adalah seluruh nasabah Bank Nagari di kota Padang yang berjumlah 39781 orang data tahun 2016 (sumber dari Bank Nagari).

Dengan tingkat standar error $(\mathrm{e}=10 \%)$, maka penulis mengambil sample sebanyak 100 orang responden yang merupakan nasabah dari Bank Nagari Cabang Utama Padang.

\section{ANALISA DAN PEMBAHASAN}

\section{Demografi Responden}

Berdasarkan hasil penelitian yang dilakukan dengan penyebaran 100 lembar kuisioner penelitian yang dibagikan kepada nasabah Bank Nagari Cabang Utama Padang, ternyata hanya 98 kuisioner yang memenuhi kriteria penelitian, sedangkan dua kuisioner tidak memenuhi kriteria penelitian, karena sebagian besar pertanyaan yang diajukan tidak dijawab oleh responden.

Rata-rata responden yang menjawab pertayaan kuisioner adalah responden perempuan sebanyak 62 orang dengan persentase sebesar $63,3 \%$. Sedangkan sisanya adalah responden laki-laki yaitu sebanyak 36 orang responden dengan 
tingkat persentase $36,7 \%$.

Dari tabel 4.2 diketahui bahwa 34,7\% responden adalah responden yang berusia antara 36-40 tahun dengan jumlah responden sebanyak 34 orang responden. Selanjutnya dapat dilihat bahwa 30 orang responden berusia antara 2635 tahun dengan persentase 30,6 \% dari total responden penelitian. Sedangkan responden yang berusia diatas 40 tahun berjumlah 21 orang atau 21,4\% responden. Untuk jumlah responden terkecil adalah responden yang berumur 1825 tahun yaitu sebanyak 13 orang responden dengan persentase 13,3\% responden.

Jumlah responden terbesar yang menabung pada Bank Nagari Cabang Utama Padang jika dilihat dari pekerjaan yang dijalani responden diketahui adalah responden dengan pekerjaan sebagai pegawai swastalah responden terbesar yang menggunakan jasa Bank Nagari Cabang Utama Padang yaitu berjumlah 47 orang dari total responden dengan persentase sebesar $48 \%$. Sedangkan responden terbesar kedua yang menggunakan jasa pada Bank Nagari adalah responden yang berkerja sebagai pegawai negeri yaitu sebanyak 31 orang repsonden dengan persentase sebesar $31,6 \%$. Selanjutnya 11 orang responden bekerja sebagai wiraswasta, sisanya adalah responden dengan kriteria pekerjaan lain-lain yaitu sebanyak 9 orang responden dengan persentase sebesar 9,2\%.

Responden terbesar yang menabung pada Bank Nagari Cabang Utama Padang adalah responden dengan pendapatan perbulan besar dari 2.000.000, terbukti dengan jumlah responden 39 orang dengan persentase sebesar 39,9\%. Selanjutnya responden terbesar kedua adalah responden yang berpendapatan antara $1.500 .000-2.000 .000$ yaitu sebanyak 29 orang responden atau dengan persentase sebesar $29,6 \%$. Sedangkan 24 orang responden berpendapatan antara 1.000.000 - 1.500.000, sisanya adalah responden dengan pendapatan kecil dari 1.000.000 perbulan sebanyak 6 orang responden.

\section{HASIL PENELITIAN}

1. Uji Normalitas

Bahwa nilai asymp.sig (2-tailed) menunjukkan nilai > dari 0.05 , yaitu 0.622 Dengan demikian data dapat dikatakan berdistribusi normal.

2. Uji Heterokedastisitas

Bahwa nilai sig menunjukkan nilai < dari 0.05 , itu dapat diartikan terjadi heteroskedasitas yang mana pada variabel X1 0,090, dan X2 0,200.

3. Uji Multikolinearitas

Variabel pelayanan $\left(\mathrm{X}_{1}\right)$ dengan nilai VIF 1,778 dan variabel teknologi $\left(\mathrm{X}_{2}\right)$ dengan nilai VIF 1,778. Pada variabel pelayanan $\left(\mathrm{X}_{1}\right)$ dengan nilai tolerance 0,562 dan variabel teknologi $\left(\mathrm{X}_{2}\right)$ dengan nilai tolerance 0,562. Dengan demikian dapat dikatakan bahwa tidak terdapat korelasi variabel-variabel bebas antara satu dengan yang lainnya, atau variabel independent pada penelitian ini bebas multikolineritas.

4. Uji Regresi Sederhana

Nilai koefisien regresi setiap variabel yang digunakan dapat dibentuk ke dalam sebuah persamaan regresi linear berganda yaitu :

$\mathrm{Y}=\mathbf{1 0 . 5 0 8}+\mathbf{0 . 1 7 8} \mathrm{X} 1+\mathbf{0 . 4 0 0} \mathrm{X} 2$

Dari persamaan tersebut diketahui bahwa variabel independen pertama yaitu 
pelayanan memiliki koefisien regresi berslope positif sebesar 0.178 . Koefisien regresi tersebut memiliki arti semakin baik pelayanan yang diberikan kepada konsumen semakin tinggi pula loyalitas nasabah terhadap Bank Nagari dengan asumsi faktor lain selain pelayanan dianggap tetap atau konstan.

Untuk variabel independen kedua yaitu teknologi ditemukan nilai koefisien regresi sebesar 0.400. Nilai koefisien regresi yang terbentuk adalah berslope positif. Hal ini membuktikan adanya pengaruh positif antara variable teknologi dengan loyalitas nasabah.

5. Uji Hipotesis

Untuk nilai variabel diperoleh nilai signifikan sebesar 0.000 sedangkan dalam melakukan pengujian digunakan tingkat kesalahan 0.05 sehingga dari hasil yang ditemukan dinyatakan bahwa sig $0.000<$ alpha 0.05 , sehingga keputusannya adalah Ho ditolak dan Ha diterima maka dapat disimpulkan bahwa pelayanan dan teknologi berpengaruh signifikan terhadap loyalitas nasabah Bank Nagari.

bahwa untuk variabel independen pertama yang diukur dengan pelayanan ditemukan nilai signifikan sebesar 0,046. dalam melakukan pengujian ditetapkan kesalahan maksimum konsisten menggunakan alpha 0,05 berarti sig $0,046<$ alpha 0,05 oleh sebab itu keputusannya adalah Ha diterima oleh Ho ditolak maka dapat disimpulkan bahwa pelayanan berpengaruh signifikasi terhadap loyalitas nasabah Bank Nagari.

Untuk hasil pengujian hipotesis variabel independen kedua yang diukur dengan teknologi ditemukan nilai signifikan sebesar 0,000. Dalam melakukan penggujian ditetapkan kesalahan maksimum konsisten menggunakan alpha 0,05 berarti sig $0,000<$ alpha 0,05 oleh sebab itu keputusan adalah $\mathrm{Ha}$ diterima dan Ho ditolak maka dapat disimpulkan bahwa teknologi berpengaruh signifikan terhadap loyalitas nasabah Bank Nagari.

Nilai $\mathrm{R}^{2}$ sebesar 0.652 hal ini mengidentifikasikan bahwa variasi proporsi yang menjelaskan kontribusi pelayanan dan teknologi secara bersama-sama terhadap loyalitas nasabah Bank Nagari adalah sebesar 0.652 atau $65.2 \%$ sedangkan sisanya lagi dijelaskan oleh variabel lain yang tidak digunakan dalam penelitian ini.

\section{PEMBAHASAN}

Berdasarkan hasil pengujian hipotesis pertama ditemukan bahwa pelayanan berpengaruh signifikan terhadap loyalitas nasabah. Hasil penelitian ini didukung oleh hasil penyebaran kuisioner. Hal tersebut dibuktikan dengan adanya 61 orang atau $62,2 \%$ responden menyatakan sangat tertarik dengan penataan eksterior dan interior perusahaan. Selain itu, 60 orang atau $61,2 \%$ responden menyatakan bahwa layanan yang diberikan oleh perusahaan cukup memuaskan nasabah. Dari keresponsifan, 49 orang atau 50\% responden menilai ketanggapan perusahaan dalam menanggapi keluhan nasabah cukup baik. Selain itu, 57 orang atau 58,2\% responden juga menilai bahwa karyawan sangat ramah dan sopan dalam melayani nasabah. Pada indikator empati, 49 orang atau $50 \%$ responden menyatakan bahwa layanan yang diberikan perusahaan berlaku umum tanpa 
membedakan status sosial dari nasabah.

Pada hasil pengujian hipotesis yang kedua ditemukan bahwa teknologi juga berpengaruh signifikan terhadap loyalitas nasabah Bank Nagari Cabang Utama Padang. Hasil penelitian ini didukung oleh hasil penyebaran kuisioner. Hal tersebut dibuktikan dengan adanya 51 orang atau 52,1\% responden menyatakan bahwa sistem komputer yang diterapkan perusahaan sudah semakin baik serta peralatan elektronik yang digunakan juga semakin canggih. Selain itu ditemukan 43 orang atau 43,8\% responden menyatakan bahwa sistem antrian yang diterapkan perusahaan sudah semakin baik karena telah terkomputerisasi. Selain itu, 53 orang atau $54,1 \%$ responden menilai bahwa perusahaan telah memiliki sistem informasi manajemen yang baik. Pada indikator tenaga ahli ditemukan 59 orang atau $60,2 \%$ responden menyatakan bahwa karyawan perusahaan sangat profesional dalam memberikan pelayanan terhadap nasabah.

Hasil yang ditemukan dalam penelitian ini sesuai dengan teori yang dikemukakan (Kotler, 2003) yang mengungkapkan bahwa loyalitas konsumen akan ditimbulkan oleh pelayanan yang diberikan sebuah perusahaan. Penyebabnya adalah semakin tinggi kualitas pelayanan yang diberikan oleh perusahaan maka konsumen akan lebih loyal dan tidak akan berpindah ke perusahaan pesaing. Dan juga teori yang dikemukakan (Riduwan, 2005) mengungkapkan bahwa loyalitas konsumen juga ditimbulkan oleh teknologi yang ada dalam sebuah perusahaan. Dalam hal ini yang dimaksud dengan teknologi adalah fasilitas teknologi yang diberikan perusahaan dalam mengatasi masalah nasabah dengan hasil yang lebih akurat dengan memberikan nilai tambah bagi nasabah.

\section{SIMPULAN}

Berdasarkan pembahasan dan analisa yang telah dijelaskan dalam bab sebelumnya mengenai pengaruh pelayanan dan teknologi terhadap loyalitas nasabah Bank Nagari Cabang Utama Padang dapat diambil kesimpulan sebagai berikut :

1. Setelah dilakukan pengujian regresi untuk variabel independen pertama yang diukur dengan variabel pelayanan ditemukan nilai signifikan sebesar 0.046. Dalam melakukan pengujian ditetapkan kesalahan maksimum konsisten menggunakan aplha 0.05 berarti sig $0.046<$ alpha 0.05 . Oleh sebab itu keputusannya adalah Ha diterima dan Ho ditolak maka dapat disimpulkan bahwa pelayanan berpengaruh signifikan terhadap loyalitas nasabah Bank Nagari Cabang Utama Padang, artinya semakin baik pelayanan yang diberikan maka loyalitas nasabah akan tercipta.

2. Hasil pengujian hipotesis variabel independen kedua yang diukur dengan teknologi ditemukan nilai signifikan sebesar 0.000. Dalam melakukan pengujian hipotesis ditetapkan kesalahan maksimum konsisten menggunakan alpha 0.05 berarti sig $0.000<$ alpha 0.05 Oleh sebab itu keputusannya adalah Ha diterima dan Ho ditolak. Maka dapat disimpulkan bahwa teknologi berpengaruh signifikan terhadap loyalitas nasabah Bank Nagari Cabang Utama Padang. 


\section{DAFTAR PUSTAKA}

Ahmad, K. (2004). Dasar-Dasar Manajemen Investasi dan Portofolio. Jakarta: PT. Rineka Cipta.

Angle, \& Perry. (2003). Model Manajemen Sumber Daya Manusia Indonesia. Jakarta: Bumi Aksara.

Arikunto, S. (2010). Prosedur Penelitian Suatu Pendekatan Praktis. Jakarta: PT. Rineka Cipta.

Aziz, N. (2019). Pengaruh Kualitas Layanan Terhadap Kepuasan Nasabah SMS Banking Pada Bank Nagari Cabang Pembantu RSUP DR M Djamil Padang. https://doi.org/10.17605/OSF.IO/S3JVG

Brady, M. K., \& Cronin, J. J. (2001). Some new thoughts on conceptualizing perceived service quality: A hierarchical approach. The Journal of Marketing, 65, 34-49.

Fernandes, Y. D., \& Marlius, D. (2018). Peranan Customer Service Dalam Meningkatkan Pelayanan Kepada Nasabah Pada PT. Bank Pembangunan Daerah Sumatera Barat Cabang Utama Padang. https://doi.org/10.31227/osf.io/wrh3p

Fernos, J., \& Putra, Y. E. (2019). Analisa Pengaruh Kualitas Pelayanan Terhadap Kepuasan Nasabah Pada PT. Bank Mega Syari'ah Padang. https://doi.org/10.31219/osf.io/y2baf

Ghozali. (2012). Aplikasi Analisis Multivariate Dengan Program SPSS. Jakarta: Liberty.

Hill, N., \& Alexander, J. (2000). Stock Image Handbook of Customer Satisfaction and Loyalty Measurement (2nd ed.). United Kingdom: Gower Pub Co.

Kotler, P. (2003). Manajemen Pemasaran (Kesebelas). Jakarta: Indeks.

Leboeuf, M. (2007). Memenangkan dan Memelihara Pelanggan. Jakarta: Pustaka.

Lovelock, Christopher Jochen, W., \& Jacky, M. (2011). Pemasaran Jasa (7th ed.). Jakarta: Erlangga. 
Marlius, D. (2018). Loyalitas Nasabah Bank Nagari Syariah Cabang Bukittinggi Dilihat Dari Kualitas Pelayanan. Jurnal Pundi. Volume 1. No. 3. Hal.1222. https://doi.org/10.31575/jp.v1i3.60

Marlius, D. (2018). Pengaruh Dimensi Kualitas Pelayanan Website Akademik Terhadap Kepuasan Mahasiswa Pada STIE "KBP". Jurnal Ipteks Terapan. Volume 12. No. 2. Hal. 116-128. http://doi.org/10.22216/jit.2018.v12i2.633

Marno, \& Idris, M. (2008). Strategi dan Metode Pengajaran. Yogyakarta: Ar-Ruz Media Group.

Mayliza, R. (2019). Pengaruh Citra Perusahaan (Corporate Image) Dan Penanganan Keluhan (Complaint Handling) Terhadap Loyalitas Pelanggan (Loyality) Natasha Skin Care Di Kota Padang. https://doi.org/10.17605/OSF.IO/DF9XJ

Mulyadi, H., \& Susanti, F. (2018). Pengaruh Penerapan Strategi Customer Relationship Marketing Terhadap Kepuasan Nasabah Pada PT. Pro Car International Finance Cabang Padang. https://doi.org/10.31227/osf.io/bhq8d

Naresh K, M. (2010). Marketing Research: An Applied Orientation (6th ed.). Prentice Hall.

Putra, Y. E., \& Aziz, N. (2019). Pengaruh Kualitas Pelayanan Dan Kepuasan Pelanggan Terhadap Loyalitas Nasabah PT. Bank Rakyat Indonesia Cabang Padang. https://doi.org/10.31219/osf.io/hcsw2

Riduwan. (2005). Skala Pengukuran Variabel-Variabel Penelitian. Bandung: Alfabeta.

Safitri, R. N., \& Marlius, D. (2017). Penerapan E-Banking Dalam Meningkatkan Jasa Dan Layanan Perbankan Di PT. Bank Rakyat Indonesia Cabang Padang. https://doi.org/10.31227/osf.io/gkv8t

Saladin, D. (2004). Manajemen Pemasaran (Keempat). Bandung: Linda Karya.

Simamora, B. (2002). Panduan Riset Perilaku Konsumen. Jakarta: PT. Gramedia Pustaka Utama.

Siswanto. (2005). Pengantar Manajemen. Jakarta: PT. Bumi Aksara.

Sugiyono. (2015). Metode Penelitian Pendidikan (Pendekatan Kuantitatif, Kualitatif dan R\&D). Bandung: Alfabeta. 
Susanti, F. W Ekazaputri. (2018). Service Performance Dan Kepuasan Sebagai Moderating Variabel Terhadap Loyalitas Nasabah Pada PT BPR Labuh Gunung Payakumbuh Jurnal Benefita: Ekonomi Pembangunan Manajemen Bisnis Dan Akuntansi. Volume 3. No. 3. Hal. 433444.http://doi.org/10.22216/jbe.v3i3.3472

Tiza, M. F., \& Susanti, F. (2019). Pengaruh Kualitas Pelayanan Terhadap Kepuasan Pelanggan, Studi kasus pada perusahaan JNE Cabang Padang. https://doi.org/10.31227/osf.io/hx87m

Ulfa, M., \& Mayliza, R. (2019). Pengaruh Kualitas Pelayanan Dan Kepuasan Pelanggan Terhadap Loyalitas Pelanggan PDAM Kota Padang. https://doi.org/10.31219/osf.io/spmgv

Umar, H. (2013). Metode Penelitian untuk Skripsi dan Tesis. Jakarta: Rajawali.

Yazid. (2008). Pemasaran Jasa Konsep dan Implementasi. Yogyakarta: Ekonisia.

Zeithaml, Valarie A., M. J. B. dan D. D. G. (2006). Services Marketing. Integrating Customer Focus Across the Firm. (4th ed.). McGraw-Hill: International Edition. Singapore. 